\title{
A Place-Based Approach in EU Regional Development and Its Application in Latvia
}

\author{
Lìga Baltiņa \\ Faculty of Economics and Management, \\ University of Latvia \\ Aspazijas blv. 5 , \\ Riga LV-1050, Latvia \\ E-mail: baltina.lu@gmail.com
}

Abstract: The EU's regional development policy is gradually moving from the reduction of regional disparities towards regional development growth. The role and involvement of regional and local authorities in regional development policy is increasing. Global changes and challenges call for a growing need to develop more efficient regional development policy instruments that would result in growth and increased quality of life. Place-based approach is a strategic approach aimed at the development of territorial resources. The aim of this research is to evaluate the role of place-based approach in regional development, to identify and assess the main elements and opportunities brought by the implementation of such an approach.

Keywords: place-based approach, regional development, territorial cohesion

\section{Introduction}

The balanced and sustainable development of regions is one of the European Union's (EU) and its Member States' top priorities, which became particularly acute with the changes in economic situation of some countries caused by the onset of the 2008 global financial and governmental crisis. The socioeconomic indicators of most EU countries have still not returned to the precrisis levels and regional disparities between EU regions have even increased. This situation has drawn attention to the issue of the efficiency of the regional development policy implemented in the EU Member States, intensified by a 
decrease of available financial resources, as well as preparations for the 2014$2020 \mathrm{EU}$ funds planning period. The question of planning and implementing new approaches to regional development policy, including more efficient use of territorial resources, has become crucial. A place-based regional development approach is put forward as a solution to promote regional development and is a topical EU discussion point. This approach covers the cooperation between sectors, the creation of new planning and management tools, the search for new forms of governance towards finding the most effective approach to the development of territorial resources and to contributing to the improvement of socio-economic indicators.

The paper aims to evaluate the role of the place-based approach in regional development policy, identify and evaluate its characteristics and analyze the application possibilities of place-based approach in Latvia.

\section{Territorial dimension in regional development theories}

The paper reviews those regional development theories which emphasize the role of territorial dimension and outlines the need for the place-based approach in regional policy. Several authors of the early $21^{\text {st }}$ century have increasingly focused on the impact of the territorial dimension on the development of individual sectors. Dawkins (2007) started wider research on the impact of the territorial dimension on the development of labour market and housing, and has pointed out its importance in regional development policy. Paulsen (2013), in turn, emphasized the role of governance in linking the labour market and housing policies with regional development. The fact that most businesses are located in areas which contribute to revenue growth (in capitals and other major cities and in their vicinity), and the population chooses the place of residence that presents greater long-term benefits (services, labour market opportunities, etc.), shows that the geographical location is of great importance.

Also, the importance of territorial accessibility is recognized by the fact that regions with higher accessibility are also more economically successful (ESPON, 2009). The cumulative causation theory alleges that poorer areas can benefit from the growth of better developed regions (Auerbach, 2009). This theory is associated with efforts to promote interaction between urban and rural areas and provide knowledge transfer from higher developed centres to less developed territories. This could be one of the directions of regional development in countries in which there is a distinct dominance of one or few 
cities. The growth pole theory explains the interaction between businesses and economic development, and stresses that by locating businesses in regions, regional growth is promoted (Teece, 2011).

The new economic geography theory explains the link between geographical location and the economic development of nations and regions. This theory discusses a more flexible approach to the use of geographical space (Wood $\&$ Roberts, 2012). It is emphasized that regions should not facilitate mutual competitiveness but create a more business-friendly environment. The new economic geography theory sees benefits in urban development as a spatially concentrated economy can grow faster (Alexiadis, 2013). The endogenous growth theory argues that national economic growth is a direct result of internal processes and that the development of human resources contributes to economic growth through new technologies and means of efficient production and service provision (Hiro, 2008). Supporters of this theory emphasize the need for government and private sector institutions to be creative, because knowledge determines economic growth (Aghion \& Howitt, 2009). This theory shows that policies geared towards openness, collaboration, change and innovation can contribute to growth, while policies that are focused on constraints, such as protecting certain spheres of production or services, hamper growth in the long term (Howitt, 2007). The exogenous growth theory, in turn, explains growth as the result of influence of external conditions (Nijkamp, 2011).

The question as to why areas with similar territorial resources have different social and economic indicators is analyzed by institutional theories. They advocate the view that institutions create the economy's ability to use and develop resources. Several authors (Olsen, 2010; Karlson et al., 2012) have pointed out that one of the most important elements of institutions is their ability to adapt to different circumstances. The changes in external environment create a natural demand for changes in public administration. A number of scientists (Menard \& Shirley, 2008; Chavance, 2008) believe that there is a relationship between the efficiency of institutional structures and growth. The strategic planning and cooperation rather than regular structural changes have a growing role in the realization of the place-based regional development approach. Regional development policy, by its nature, cannot exist without the collaboration between different sectors and regional and local governance (Farole et al., 2011). Several theorists of regional development (Panara \& De Backer, 2011) recognize the importance of promoting involvement of regional and local governments and the nongovernmental sector in decision-making, as well as examining the possibility to delegate the responsibility to the regional and local government. 
An increasing number of regional development researchers are analyzing the role of immaterial factors in promoting regional development, such as participation in collaborative networks and the development of social capital (Capello et al., 2008; Capello \& Dentinho, 2012). Karlson concludes that the regions which are actively involved in various collaborative networks are more capable of seeing opportunities and mobilizing their resources to promote regional development and considers the collaborative networks a significant social capital (Karlson et al., 2012). Collaborative networks have a growing importance in the development of territorial resources.

It should be noted that it is impossible to rely exclusively on one theory, as the processes of economic development and factors affecting them must be examined together with an analysis of the characteristics of the area (Barca \& McCann, 2012). The analysis of place-based approach is a topical subject of research in regional development and demonstrates its issues and multidimensional nature.

The place-based approach combines the key theories that highlight the characteristics of a location, available resources and institutions, as well as emphasizes additional elements such as collaboration, adaptability, territorial resource management capability and the interaction of different territorial elements.

\section{The territorial dimension in EU regional development initiatives}

The origins of a common EU approach to regional development policy can be traced back to 1957 when six countries signed the Treaty of Rome in order to strengthen economic unity and achieve balanced development by reducing regional disparities and helping regions with lower socio-economic indicators. Reducing of regional disparities became especially important in 1986 when Greece, Spain and Portugal joined the EU (according to the European Union's Statistics Office, Eurostat, analysis of GDP data). After the EU expansion in 2004 and 2007, there are still significant regional differences between the Member States (according to Eurostat, GDP per capita). Although the current EU regional development policy focuses on reducing disparities between EU countries and regions, research on the development of the labour market and the EU's cohesion policy has shown that significant disparity in economic indicators can still be observed between regions of the EU, having even increased over time (Caroleo \& Pastore, 2010; Molle, 2011; Adams et al., 2012; Blizkovsky, 2012). 
Every year the issue of territorial cohesion has attracted more attention, explaining the differences between the economic, social and territorial cohesion, emphasizing the interaction between urban and rural areas and the assessment of geographical differences between territories (EC, 2007; Prezioso, 2008). However, the analysis of EU documents showed that EU institutions and Member States do not have a common position on territorial cohesion goals, objectives and the factors influencing it.

In 2010, the conditions of strategy "Europe 2020" were put forward, proposing that all decisions should take into account the territorial dimension, and improve decision-making and management mechanisms (EC, 2010). This, in turn, pointed out the need for cooperation in sectoral policy and the need for multilevel governance (Grzeszczak \& Karolewski, 2012).

An analysis of EU regional development policy documents showed a gradual change in regional development policy objectives - a transition from reduction of regional disparities and support for underdeveloped areas to promotion of regional growth and the growing role of the territorial dimension in regional development policy (Barca, 2009; Mendez et al., 2011). Although the EU Member States still have not agreed on the definition of territorial cohesion, its aims have been set - to promote coherent and sustainable development of all territories based on territorial differences and resources, through an integrated approach, multi-level governance and cooperation. Consequently, the main principles of EU regional policy are: multi-level governance and subsidiarity, proportionality, complementarity, coordination, collaboration and partnerships, monitoring and evaluation (Servillo, 2010). Regarding cooperation, the need to develop the non-governmental sector in the EU as an equal partner in regional policy planning and implementation becomes of greater importance, promoting compliance with the partnership principle.

The 2008 economic and financial crisis was one of the most visible examples of when the need for changes in regional development policy, including the revision of the regional development strategies and search for adequate tools for addressing the regional development needs were stressed.

According to the author's analysis, the EU regional development policy shows three main trends:

1) The increasing role of the territorial dimension, including the development of territorial resources;

2) More active involvement of regional and local level government in regional development policy planning and implementation; 
3) Improvement of the institutional structure, including the promotion of mutual cooperation between sectoral policies.

The OECD also noted, while conducting an analysis of the changes to EU's regional development policy, a shift from a sectoral to an integrated approach and from the compensation mechanisms for regional disparities to improving the results of regional development (OECD, 2009).

\section{A need for a place-based approach to regional development}

A need for a place-based approach to regional development is based on a situation in which the socio-economic differences between regions are interpreted differently in the analysed theories, citing the impact of technology on economic development, geographical location, institutional differences and the deployment of economic activities in major cities and in their vicinity, and other factors.

The analysis of literature on regional development and management revealed a number of factors which emphasize the role of the territorial dimension and indicate the need to implement the place-based approach:

1) Each territory has a different set of available resources, including institutional, to the development of which a single approach cannot be applied (Stead, 2013);

2) The increasing globalization has a territorial nature and its impact on the development of EU regions is different (e.g., climate change, migration) (Walsh, 2013);

3) The changes in external environment are processes that can be used in regional development and whose management requires adequate institutional capacity and flexibility in regard to possible solutions to problems (Dunleavy et al., 2006);

4) Sustainable development of territorial resources involves the need to simultaneously address economic, environmental and social issues (Adams et al., 2012).

OECD called place-based approach a new model for formulating and solving problems in regional policy (Lumina, 2012), indicating that economic growth is dependent on resource management skills. Several international organizations (World Bank, 2008; EU, 2009; OECD, 2009) in search of an integrated approach are arriving at the need to implement the place-based approach that takes into 
account the characteristics of the territory, territorial resources, and institutional capacity to manage them and the development potential of the area (Baltina, 2011).

Several authors emphasize the dynamics of regional development, which means that the growth in adjacent areas and the economic benefits it brings may play an important role in the development of the territory (Capello et al., 2008; Fritsch \& Noseleit, 2013). In discussions on the improvement of the EU's cohesion policy it was concluded that an excessively broad cohesion policy is infeasible in relation to its objectives (Baltina \& Muravska, 2012). The analysis showed that one of the problems is the general character of regional development policy and that not enough attention is devoted to economic activity and the need for innovation and support for entrepreneurship in regional development (Dall'erba et al., 2011; Zonneveld et al., 2012).

In recent years, regions are increasingly seen as a source of economic growth (Diedrichs et al., 2011; Panara \& De Backer, 2011) and it is noted that territorial disparities may be rooted in the rigidness of the institutional system of regional development (Sabel \& Zeitlin, 2010). This suggests that the need for better planning and utilization of territorial resources increases the role of institutions involved in the planning and implementation of regional development policy. Cooperation between national, regional and local government institutions and organizations is seen as the most important prerequisite in achieving efficient public administration (Acemoglu, 2010; Faludi, 2010; Crescenzi \& Percoco, 2012). Modern theories on regional development distinguish between three types of cooperation-building processes: market-driven cooperation, policydriven cooperation and idea-driven cooperation (Tosics, 2011). Although it is possible that cooperation can be achieved, based on the needs of the market as well as the political decisions and ideas, one of these will always be the determining factor.

The author believes that for the regions to maintain and promote their competitiveness, regional development strategies should include a regular survey of territorial resources in accordance with changes in external environmental. This approach is called the potential opportunity dynamics (Teece \& Helfat, 2007). Several authors emphasize that in the long-term development planning resource dynamics is important because it is linked to the region's ability to create interaction between the available resources in a changing environment and covers innovation, learning, cooperation, management and forecasting capabilities (Cooke et al., 2012). 
In the light of the study, the author has concluded that the move in EU regional policy towards the use of a place-based approach in regional development planning and implementation has to be carried out in accordance with development trends in public administration that outline:

1) Policy integration and cooperation of institutions (integration of environmental, economic and social issues in regional development policy);

2) Long-term plan, which provides for changes according to environment, in order to ensure preventive action to eliminate possible problems;

3) Focus on results through policy evaluation tools for determining the policy's environmental, economic and social contributions and benefits;

4) Move towards cooperation, which includes the participation of regional and local governments and stakeholders, ensuring full involvement and establishing responsibility for achieving results at a regional and local level.

Between the EU institutions and Member States there is an ongoing discussion on the examples of good practice regarding the regional development instruments that emphasize place-based approach. In the search for the most suitable instruments for implementing regional development policy, the placebased approach emphasizes the need to experiment. In the EU countries overall, discussions have started about a more efficient utilization of resources, which requires clear priorities in regional development policy, as well as finding a balance between the needs of the cities and the less developed regions, and between the needs of large-scale infrastructure and innovation challenges.

\section{A potential for the implementation of place-based approach in regional development in Latvia}

Although one of the objectives of Latvian accession to the EU was the steady development of the whole country in order to promote the well-being and quality of life not only in Riga and major Latvian cities, but also in other regions and rural areas (Ministry of Foreign Affairs, 2006), there is a continuous presence of significant regional differences in Latvia. The socio-economic indicators in most of the Latvian regions are still below the EU average, which raises the question of the effectiveness of regional development policies in the country.

In order to better understand the possibilities of implementing the place-based approach to regional development policy in Latvia, the author carried out an 
analysis of the institutional and legal framework of the regional development policy. The study showed that the number of institutions involved in the coordination of regional development matters is too large and dependence on funding from EU funds for regional development activities is too great. Other authors have also noted that there are uncertainties regarding the division of responsibilities (Vaidere et al., 2006). The author observed that the main problem in Latvia since 1991 has been that regional development policy is viewed as a supporting tool for achieving economic goals rather than a consistent long-term policy. When in 2008 the economic downturn began, and an urgent need to reduce government spending arose, the search for changes in the direction in Latvian regional development started. It showed that the changes in Latvian regional development policy are basically driven by an external crisis, which was mainly related to budget cuts.

Over time, regional development issues have been under the competence of a number of ministries and their subordinate authorities. A separate Ministry of Regional Development and Local Government Affairs was established only in 2003, but since its merging with the Ministry of Environmental Protection in January 2011, the Ministry of Environmental Protection and Regional Development is the main institution responsible for regional development policy in Latvia. Currently, several institutions in Latvia are involved in the planning and implementation of regional development policy. Their main tasks in planning and implementation of regional development policy are summarized in Table 1.

At the government and ministerial level there is uncertainty about the legal framework of regional development in Latvia, the allocation of responsibilities and mutual coordination.

In Latvia, the application of the place-based approach was planned in the National Development Plan (NDP) for 2014-2020. However, in the NDP of 2014-2020, approved in December 2012, this approach, referred to as an "integrated territorial approach", is only mentioned in a polycentric development and urban context (Cross-Sectoral Coordination Centre, 2012). Regarding institutional framework for regional policy, in the regional policy guidelines project (MEPRD 2012) the designation of MEPRD as the single managing authority is presented as a major breakthrough, thus demonstrating the centralized approach to regional planning and avoiding the assessment of the existing roles and status of the planning regions. The NDP 2014-2020, in regard to the development of territory potential, which is one of the cornerstones of the place-based approach, stresses only the role of cooperation between border areas. The planning regions, in turn, are expected to promote the involvement of local governments and citizens of smaller counties in the realized investment projects. 
Table 1. Key institutions responsible for regional development policy issues in Latvia in 2012.

\begin{tabular}{|c|c|}
\hline Institution & $\begin{array}{l}\text { Main tasks related to the planning and } \\
\text { implementation of regional development policy }\end{array}$ \\
\hline The Cabinet of Ministers & $\begin{array}{l}\text { The approval of the main planning documents (e.g., } \\
\text { policy guidelines, National Development Plans and } \\
\text { others) }\end{array}$ \\
\hline $\begin{array}{l}\text { National Regional } \\
\text { Development Council }\end{array}$ & $\begin{array}{l}\text { Advisory support on issues of coordination, } \\
\text { concerning regional development, territorial } \\
\text { planning and land policy in the state }\end{array}$ \\
\hline $\begin{array}{l}\text { Ministry of Environmental } \\
\text { Protection and Regional } \\
\text { Development }\end{array}$ & $\begin{array}{l}\text { The planning and implementation of regional } \\
\text { development policy in Latvia }\end{array}$ \\
\hline $\begin{array}{l}\text { State Regional } \\
\text { Development Agency }\end{array}$ & $\begin{array}{l}\text { Implementation of regional development policy, } \\
\text { particularly the administration of EU funds and } \\
\text { national regional development programs }\end{array}$ \\
\hline $\begin{array}{l}\text { Cross-Sectoral } \\
\text { Coordination Centre } \\
\text { (directly subordinated to the } \\
\text { Prime Minister) }\end{array}$ & $\begin{array}{l}\text { Ensuring the mutual coherence of national-level } \\
\text { planning documents and their compliance with } \\
\text { regulations }\end{array}$ \\
\hline $\begin{array}{l}\text { Reform Management } \\
\text { Group }\end{array}$ & $\begin{array}{l}\text { Provision of public participation in the preparation } \\
\text { of state budget, implementation of reforms and in } \\
\text { other important state decisions }\end{array}$ \\
\hline $\begin{array}{l}\text { Planning Areas (derived } \\
\text { public persons) }\end{array}$ & $\begin{array}{l}\text { Ensuring of cooperation between regional } \\
\text { development planning, coordination, local } \\
\text { government and other public authorities within its } \\
\text { jurisdiction }\end{array}$ \\
\hline $\begin{array}{l}\text { Planning Region } \\
\text { Development Councils }\end{array}$ & $\begin{array}{l}\text { Approval of regulations and budget of planning } \\
\text { regions, resolution of issues concerning institutions, } \\
\text { capital companies and other financial issues within } \\
\text { a region }\end{array}$ \\
\hline Local governments & $\begin{array}{l}\text { Advancement of development programs and } \\
\text { planning of the local government's territory, } \\
\text { implementation of the territorial development } \\
\text { programs and administrative supervision of } \\
\text { territorial planning }\end{array}$ \\
\hline Sectoral ministries & $\begin{array}{l}\text { Participation in the National Regional Development } \\
\text { Council }\end{array}$ \\
\hline
\end{tabular}

Source: Table created by the author on the basis of regulations of the Republic of Latvia 
The author concluded that Latvian regional development policy demonstrates only a few features of the place-based approach. The appreciation and development of territorial resource potential is the weakest link in Latvian regional development policy, as evidenced by the analyzed documents on regional development planning and implementation, other thematic studies on regional development issues and a poll conducted by local governments.

The trends of EU regional policy's development, analyzed in this study, indicated an increased role of the regions in achieving the objectives of cohesion policy (Zonneveld et al., 2012). Institutional theories emphasize that a model of territorial governance must be sufficiently flexible to enable it to respond to changes in the economic and social environment, with an appropriate course of action. Accordingly, regions no longer represent just a clearly defined administrative unit, but an area for policy implementation (Dale et al., 2012). In Latvia, the role of regions has been the subject of discussion for many years, without arriving at a unified position. In Latvian regulations, the term 'region' is not specifically explained and is basically used as a designation of administrative division. Since 2006, planning regions, in turn, are designated in Latvia as derived public persons and are under the supervision of the Ministry for Environmental Protection and Regional Development.

Since the 1990s, a number of regional development studies have emphasized the need for strong regions that can propose regional priorities and represent regional interests in Latvian politics. Due to their currently uncertain status, the planning regions have not contributed to the cooperation between the local governments of a relevant region, and have not provided a link between local governments and the state's administrative institutions (UN, 2005). The poll of local governments, carried out in the framework of this study, also points out the obscure role of the regional level government or even its non-existence. When analyzing the role of Latvia's regions in regional development, it is essential to understand the current status of the planning region. Although the Regional Development Law determines the legal status of the planning regions and their matters within their competence, the current status is viewed as a transitional solution and a significant shortcoming of the planning regions is their disconnectedness from society (SRDA, 2012).

Riga, as the nation's capital city, is clearly dominant in Latvia. However, the author's analysis of literature shows that Riga's dominance cannot be considered a decisive factor in regional development planning in the future; instead, 
conditions should be created for promotion of the potential of other areas and its more efficient utilization.

The benefit of using the place-based approach is that it does not require strict administrative boundaries, but rather highlights the role of the territory, where the integration of different policies may be effective and allows pursuing smallscale initiatives in a smaller area, without condition of covering the entire region. This approach allows taking action appropriate for the territorial resources and development potential that is still a challenge in Latvia.

To evaluate the regional development policy implemented since 2004, the author conducted a survey of representatives of all the 119 local governments in Latvia. The survey showed that in terms of the regional development policies implemented since 2004 and their impact on the development of the municipality, utmost importance is placed on the availability of EU funds rather than the implemented regional development initiatives. These results of the survey showed that regional development policy is not considered significant in relation to real improvements at the local and regional level.

A majority of the respondents associated the implementation of place-based approach with the need to establish clear objectives of regional development policy. The survey showed that to increase the role of local governments in regional development policy planning and implementation, better coordination between local, regional and national planning authorities as well as organizations representing various interest groups, is necessary.

The respondents highlighted the need to improve the understanding of the EU's regional development trends and regional development planning and implementation instruments. Their responses to the territorial development issues signalled the need for equal involvement of all levels of government in regional development policy planning and implementation.

The respondents' answers demonstrated the issues of regional developmentstrategic planning, improvement of infrastructure, social and educational issues - the addressing of which requires close cooperation between all levels of government. In promoting business development, the national level serves the most important role in regard to common development priorities, and the local authorities in regard to managing territorial resources and their potential. The survey showed that since the implementation of Latvia's regional development policy in 2004, its main instrument is the EU funds, but the assessment of their impact on the development of local government territories differs. The survey's results demonstrated that the current regional development policy has not paid 
sufficient attention to promoting economic activities in the region. The results show that representatives of local governments have no clear views on the role of planning regions, while highlighting the need for a clear separation of functions and responsibilities between the national, regional and local levels.

\section{The possibilities of applying place-based approach in regional development planning in Latvia}

A proper legal and institutional framework is the basis of successful achievement of regional development goals, and therefore the improvement of policy documents and their mutual coherence must be one of the starting points.

Latvia's regional development policy documents list more than 30 different regional development policy principles. This shows the necessity to review the various principles set forth in regional development policy documents, avoiding duplication and emphasizing the key principles that are essential to the place-based approach - partnership, an integrated approach, and sustainable development.

The study showed that the current regional development policy is described as inflexible as regards implementing necessary changes, because there is no clear mechanism on how public administration can review the existing policy programs to apply them in accordance with the changes in external environment. In this respect, the place-based approach includes the need to update in a timely manner the influencing factors to enhance the prevention of potential risks.

Attempts to use the place-based approach in regional development policy in Latvia can be divided in three main groups:

- Initiatives to reduce regional disparities (e.g., territories requiring special assistance program Latgale Region Action Plan 2012-2013, application restrictions based on geographical location, diversification aid intensity according to socio-economic indicators);

- Polycentric development initiatives (e.g., EU SF support program for national and regional development centres);

- Initiatives for developing territorial growth and cooperation that take into account the potential of territorial resource development, support collaborative projects and facilitate cooperation between local, regional and national levels. 
So far, practical examples of the first two groups have been implemented in Latvia's regional development policies.

There is a need to emphasize the cooperation mechanisms instead of increasing coordination efforts by

1) ensuring the compliance with the partnership principle in planning, implementation and assessment of regional development;

2) clear allocation of functions and responsibilities between the national, regional and local levels;

3) greater involvement of local and regional institutions and organizations in planning, implementation and assessment of the regional development.

In order to more effectively direct available financial resources to achieve a territory's development objectives, a growing importance is attributed to various cooperation networks. It is assumed that the institutions and organizations which are involved in different networks to spread their knowledge, acquire new knowledge and adopt examples of good practice, are more predisposed to see opportunities and mobilize their resources to promote regional development.

A study on the socio-economic development tendencies of Latvian cities showed that the cities' cooperation with their foreign partners is short-term or projectbased, not long-term programs with common development objectives (SRDA, 2008). Taking into consideration the growing role of international cooperation, there is a need for a more strategic approach to the involvement of Latvia's institutions and organizations in various international organizations; also, it is necessary to ensure mutual exchange of information on the national and regional level about the obtained information and other resources.

None of Latvia's regional development planning documents stipulate the necessity to carry out regular assessments of territorial resources. In regard to evaluation of policy, it is important not only to carry out an assessment of the impact of the implemented policy on territorial development, but also to examine the contribution of the sectoral policies in the improvement of socioeconomic indicators. In Latvia, there is no functioning regional development monitoring and assessment system that would provide adequate information for decision-making. However, the experience of other countries shows that regional development monitoring systems provide strong support for the planning and assessment of regional development policy. Even though it has to be acknowledged that systematic solutions cannot ensure the assessment of effectiveness of regional development support instruments and other estimates. It can be ensured by regular and independent analytical research on regional 
development policy issues. In studies that have been conducted so far and have been mainly commissioned by state institutions, assessment of regional development policy has not been carried out and concrete recommendations for policy improvement have not been put forward.

\section{Main conclusions}

A number of theories on regional development conclude that territorial resources, their development potential and efficient institutional framework are among the main factors that should be taken into account in regional development planning. However, none of these theories analyze all of these factors. Regional development theories do not cover such vital aspects of the analysis of territorial dimension as the role of cooperation, ability to adapt and interaction. The placebased approach combines several regional development theories and promotes the formation of a new scientific school in order to continue to study and analyze the application of this approach in regional development.

The application of the placed-based approach in regional development involves several steps:

- Evaluation of the existing territorial resources and their development potential;

- Establishing objectives for the use of territorial resources and their potential;

- Effective functioning of the institutional system;

- Regular assessment of territorial resources and changes in their potential and assessment of return of investments in the territory's development.

The current practice of implementing the place-based approach can be observed mainly in relation with the strengthening of the regions' role, implementing changes in the institutional system, and planning integrated territorial investments. The analysis showed that clearly defined regional development goals at the EU, national and regional levels are a precondition for a successful implementation of the placed-based approach.

There is no common definition of the place-based approach in regional development documents of Latvia as well as no consistency in the use of regional development terms. Such factors as the uncertain role of planning regions, lack of cooperation, and common understanding regarding the opportunities of introducing the place-based approach limit effective implementation of 
regional development goals in Latvia. Regional development planning requires improvements in cooperation between the sectors of national economy, instead of an increased coordination of policies. The research showed that one of the most common problems is an ineffective or nonexistent cooperation mechanism between the national, regional and local management levels.

The results of a survey of municipalities showed that the impacts of regional development initiatives in Latvia since 2004 are considered insignificant and that the key role in the development of Latvian territories is attributed to the availability of EU funds. Towards the implementation of the place-based approach, the following cross-sector cooperation problems should be conquered:

- Ineffective information exchange between various levels of government;

- Inefficient administrative capacity on local and regional levels;

- Discrepancy between the administrative and functional territory.

In addition, regional development monitoring system should be considered a strong support for planning and assessing regional development initiatives and there is a strong need to ensure a regular and independent assessment of the effectiveness of regional development support instruments.

Liga Baltina is a PhD candidate at the University of Latvia in Riga. She has more than ten years of experience in working with EU projects aimed at polycentric development and institutional capacity building. For more than five years she has been a member of the research and expert team at the Centre for European and Transition studies and Jean Monnet Centre of Excellence at the University of Latvia. The focus of her academic interest is place-based approach, on which she has authored several publications. She continues to be an expert at international workshops on regional development matters, territorial cooperation and EU funds management (e.g., cooperation with DATAR in France, EIPA in Spain, IMPACT centre in Croatia) and has been a designated contact person for Latvia's participation in the IQ-Net International Network on EU Structural Funds and in ESPON programme. 


\section{References}

Acemoglu, D. (2010), 'Institutions, Factor Prices and Taxation: Virtues of Strong States?'American Economic Review, vol. 100, no. 2, pp. 115-29. http://dx.doi.org/ 10.1257/aer.100.2.115

Adams, N.; Alden, J. \& Harris, N. (2012), Regional Development and Spatial Planning in an Enlarged European Union, Aldershot: Ashgate Publishing.

Aghion, P. \& Howitt, P. (2009), The Economics of Growth, Cambridge: The MIT Press.

Alexiadis, S. (2013), Convergence Clubs and Spatial Externalities: Models and Applications of Regional Convergence in Europe, Advances in Spatial Science, Berlin: Springer. http://dx.doi.org/10.1007/978-3-642-31626-5

Auerbach, A. J. (2009), 'Implementing the New Fiscal Policy Activism,' American Economic Review, vol. 99, no. 2, pp. 543-549.

http://dx.doi.org/ 10.1257/aer.99.2.543

Bachtler, J. \& Yuill, D. (2007), Regional Policy in Western Europe: Taking Stock of the Shift in Paradigm, Bochum: RUFIS.

Baltiņa, L. (2011), 'Uz vietu balstīta pieeja ES reǵionālās politikas efektivitātes uzlabošanai,' Latvijas Universitātes raksti: Ekonomika un vadības zinātne, 766. sējums. Riga: Latvijas Universitāte, pp. 106-120.

Baltiņa, L. \& Muravska, T. (2012), 'Eiropas Savienības Kohēzijas politika pēc 2013. gada. Ko tā nozīmē Latvijai?' Žurnāls “Latvijas intereses Eiropas Savienībā”,, no. 1, pp. $46-56$.

Barca, F. (2009), An Agenda for a Reformed Cohesion Policy, A Place-Based Approach to Meeting European Union Challenges and Expectations, Independent report (Brussels: DG Regio).

Barca, F. \& McCann, P. (2012), 'The Case for Regional Development Intervention: Place-based versus place-neutral approaches,' Journal of Regional Science, vol. 52, no. 1, pp. 134-152. http://dx.doi.org/10.1111/j.1467-9787.2011.00756.x

Blizkovsky, P. (2012), Does 'the Golden Rule' Translate into 'Golden'EU Economic Governance? Policy Brief, Singapore: School of Public Policy.

Caroleo, F. E. \& Pastore, F. (2010), The Labour Market Impact of the Enlargement, Berlin \& Heidelberg: Springer. http://dx.doi.org/10.1007/978-3-7908-2164-2_1

Capello, R.; Camagni, R. P.; Chizzolini, P. \& Fratesi, U., eds. (2008), Modelling Regional Scenarios for the Enlarged Europe: European Competitiveness and Global Strategies, Berlin: Springer.

Capello, R. \& Dentinho, T. P. (2012), Networks, Space and Competitiveness: Evolving Challenges for Sustainable Growth, Cheltenham: Edward Elgar Publishing. http:// dx.doi.org/10.4337/9781781003671

Chavance, B. (2008), Institutional Economics, London: Routledge. 
Cooke, B.; Langford, W. T.; Gordon, A. \& Bekessy, S. (2012), 'Social context and the role of collaborative policy making for private land conservation,' Journal of Environmental Planning and Management, vol. 55, no. 4, pp. 469-485.

http://dx.doi.org/10.1080/09640568.2011.608549

Crescenzi, R. \& Percoco, M. (2012), Geography, Institutions and Regional Economic Performance, Advances in Spatial Science, Berlin: Springer.

http://dx.doi.org/10.1007/978-3-642-33395-8_2

Dale, A.; Dushenko, W. T. \& Robinson, P. J. (2012), Urban Sustainability: Reconnecting Space and Place, Toronto: University of Toronto Press.

Dall'erba, S.; Lim, J.; Tong, D. \& Plane, D. (2011), 'New Perspectives on Regional Development,' Région et développement, vol. 33, pp. 5-8.

Dawkins, C. J. (2007), 'Space and the Measurement of Income Segregation,' Journal of Regional Science, vol. 47, no. 2, pp. 255-272.

http://dx.doi.org/10.1111/j.1467-9787.2007.00508.x

Diedrichs, U.; Reiners, W. \& Wessels, V. (2011), The Dynamics of Change in EU Governance, Cheltenham: Edward Elgar Publishing.

Dunleavy, P.; Margetts, H.; Bastow, S. \& Tinkler, J. (2006), Digital Era Governance: IT Corporations, the State and E-Government, Oxford: Oxford University Press.

EC (2010), Europe 2020: A European Strategy for smart, sustainable and inclusive growth, Communication from the Commission, COM (2010)2020, 03.03.2010, Brussels: European Commission.

ESPON (2009), 'ESPON: European Spatial Planning Observation Network. Territorial Observation No. 2,' The ESPON 2013 Programme, Nov 2009, Luxembourg.

Faludi, A. (2010), Cohesion, Coherence, Cooperation: European Spatial Planning Coming of Age? Abingdon: Routledge.

Farole, T.; Rodríguez-Pose, A. \& Storper, M. (2011), 'Cohesion policy in the European Union: Growth, geography, institutions,' JCMS: Journal of Common Market Studies, vol. 49, no. 5, pp. 1089-1111.

http://dx.doi.org/10.1111/j.1468-5965.2010.02161.x

Fritsch, M. \& Noseleit, F. (2013), 'Investigating the Anatomy of the Employment Effects of the Business Formation,' Cambridge Journal of Economics, vol. 37, no. 2, pp. 349-377. http://dx.doi.org/10.1093/cje/bes030

Grzeszczak, R. \& Karolewski, I. P. (2012), The Multi-Level and Polycentric European Union: Legal and Political Studies, Münster: LIT Verlag.

Hiro, I. (2008), 'What Does Endogenous Growth Theory Tell about Regional Economies? Empirics of R\&D Worker-based Productivity Growth Regional Studies,' Regional Studies, vol.42, no. 7, pp.947-960. http://dx.doi.org/10.1080/00343400701541847

Howitt, P. (2007), 'Edmund Phelps: Macroeconomist and Social Scientist,' The Scandinavian Journal of Economics, vol. 109, no. 2, pp. 203-224. 
Karlson, C.; Johansson, B. \& Stough, R. R. (2012), Entrepreneurship, Social Capital and Governance: Directions for the Sustainable Development and Competitiveness of Regions, Cheltenham: Edward Elgar Publishing. http://dx.doi.org/10.4337/9781781002841

OECD (2008), 'Making the Most of Regional Development Policy through Multi-level Governance,' in Territorial Reviews: Poland 2008, Paris: OECD Publishing, pp. 171-242. http://dx.doi.org/10.1787/9789264049529-5-en

— (2009), OECD Regions at a Glance, Paris: OECD Publishing.

McCann, P. (2010), Modern Urban and Regional Economics, Oxford: Oxford University Press.

Menard, C. \& Shirley, M. (2008), New Institutional Economics: Institutions and Development, Berlin: Springer.

Mendez, C.; Bachtler, J. \& Wishlade, F. (2011), Visions and Options for Cohesion Policy after 2013, Report to European Parliament, Brussels: European Parliament.

Molle, W. (2011), Economic Governance in the EU: Implementing Policies with the Financial and Coordination Modes, London: Routledge.

Muravska, T. (2012), 'Crisis in Latvia - economic transformation: the regional dimension and development constraints,' in G. Gorzelak, C. Goh \& K. Fazekas (eds.) Adaptability and Change - the Regional Dimensions in Central and Eastern Europe, Warsaw: Wydawnictwo Naukowe "Scholar", pp. 245-268.

Nijkamp, P. (2011), Innovation, Growth and Competitiveness: Dynamic Regions in the Knowledge-Based World Economy, Advances in Spatial Science, Berlin: Springer.

Olsen, J. P. (2010), Governing Through Institution Building: Institutional Theory and Recent European Experiments in Democratic Organization, Oxford: Oxford University Press.

Panara, C. \& De Backer, A., eds. (2011), The Role of the Regions in the EU Governance, Berlin: Springer. http://dx.doi.org/10.1007/978-3-642-11903-3

Paulsen, K. (2013), 'The Effects of Growth Management on the Spatial Extent of Urban Development,' Land Economics, vol. 89, no. 2, pp. 193-210.

SRDA (2008), Survey 'Trends of Social Economic Development of Towns and Cities of Latvia', Riga: The State Regional Development Agency.

_ (2012), Pārskats “Reǵionu attīstība Latvijā 2011" [Survey 'Development of Regions in Latvia 2011'], Riga: The State Regional Development Agency.

Prezioso, M. (2008), 'Is it possible to give the territorial dimension more relevance for choices of competitiveness and sustainability policies?' Transition Studies Review, vol. 15 , no. 1, pp. 1-19.

Sabel, C. \& Zeitlin, J. (2010), 'Learning from difference: the new architecture of experimentalist governance in the EU,' in C. F. Sabel \& J. Zeitlin (eds.) Experimentalist Governance in the European Union: Towards a New Architecture, Oxford: Oxford University Press, pp. 1-28. 
Servillo, L. (2010), 'Territorial Cohesion Discourses: Hegemonic Strategic Concepts in European Spatial Planning,' Planning Theory \& Practice, vol. 11, no. 3, pp. 397-416.

Solow, R. M. (2000), Growth Theory: An Exposition, $2^{\text {nd }}$ edition, Oxford: Oxford University Press.

Stead, D. (2013), 'Dimensions of territorial governance,' Planning Theory and Practice, vol. 14, no. 1, pp. 142-147. http://dx.doi.org/10.1080/14649357.2012.758494

Teece, D. (2011), Dynamic Capabilities and Strategic Management: Organizing for Innovation and growth, Oxford: Oxford University Press.

Teece, D. \& Helfat, C. E. et al. (2007), Dynamic Capabilities: Understanding Strategic Change in Organisations, Oxford \& Malden: Wiley-Blackwell.

Tosics, I. (2011), Governance Challenges and Models for the Cities of Tomorrow, Budapest: Metropolitan Research Institute.

Vaidere, I.; Vanags, E.; Vanags, I. \& Vilka, I. (2006), Regionālā politika un pašvaldību attīstība Eiropas Savienībā un Latvijā, Rīga: LU Akadēmiskais apgāds.

Walsh, J. (2013), 'Remapping the border: geospatial technologies and border activism,' Environment and Planning D: Society and Space, vol. 31, no. 6, pp. 969-987.

Wood, A. \& Roberts, S. (2012), Economic Geography: Places, Networks and Flows, Abingdon: Routledge.

World Bank (2009), World Development Report 2009: Reshaping Economic Geography, Washington, DC: World Bank.

Zonneveld, W.; De Vries, J. \& Janssen-Jansen, L., eds. (2012), European Territorial Governance, Housing and Urban Policy Studies, vol. 35, Amsterdam: IOS Press. 